\title{
Net Zero Energy House in Serbian Conditions for Kragujevac
}

\author{
Jelica Dimitrijević ${ }^{1}$ Stefan Pantović2,* \\ ${ }^{1}$ Faculty of engineering in Kragujevac, University of Kragujevac \\ ${ }^{2}$ Faculty of Mechanical and Civil Engineering in Kraljevo, University of Kragujevac
}

This study explores the feasibility of solar Net Zero Energy Building (NZEB systems for a four typical family house in the climatic zone of the city of Kragujevac. The building uses electricity for lighting and electrical appliances. Electricity is produced by photovoltaic panels, which are connected to the grid for heating uses natural gas, while the solar panels used to heat hot water. The buildings are presented by a mathematical model, in EnergyPlus environment and Open Studio plug-in in Google SketchUp was used for building virtual design. Results show the calculation of net zero home. Net zero home produces all the energy through renewable energy, which spends for its own purposes.

\section{Keywords: NZEB, NZEH, Simulation, Climate, Energy.}

\section{INTRODUCTION}

In Serbia the built environment consumes around $50 \%$ of the primary energy. Participation of households in the total electricity consumption is $56 \%$ [1]. The energy mix for electricity production consists of around $72 \%$ of electricity produced by fossil fuel (mainly coal, and some natural gas or oil) power plants and $28 \%$ of electricity produced by hydroelectric power plants [1]. This energy mix means that $1 \mathrm{~J}$ of electricity is generated by $2.154 \mathrm{~J}$ of the primary energy. These data reveal that $1 \mathrm{~J}$ of electricity spent in buildings would generate $2.154 \mathrm{~J}$ of the primary energy consumption that has large impact to the environment.

On 24 September 2007, Serbia ratified Kyoto protocol which regulates reduction in green house gas emissions. On the other side, an intention of our country to become a member of EU obliges us to reduce energy consumption by $20 \%$ and to obtain $20 \%$ of total energy from renewable energy sources by 2020 [2]. To achieve these goals, some advanced energy concepts for built environment should be applied such as ZNEB and PNEB. In addition, the feed-in tariffs should be used that are recently established in Serbia. Currently, the feed-in tariff for electricity production by solar power plants is $0.23 \mathrm{e} / \mathrm{kW} \mathrm{h} \mathrm{[3].}$

A ZEB building can be dependent or independent of the electrical grid. As discussed by [4] and [5], with current technology, a grid disconnected ZEB is difficult to implement, both from an economical and technical viewpoint, due to the seasonal mismatch between energy demand and renewable energy supply. In the off-grid approach, the excess of renewable energy collected in the summer is wasted and cannot be used to balance energy needs during the winter period. A grid connected ZEB does not require on site electrical energy storage: any surplus in electricity production is injected into the grid, conversely, when production is insufficient, the building draws from the grid. This grid connected, energy exchange approach is called Net ZEB (NZEB): on a net annual base the building requires no energy input. In the case of houses, the most common denomination is Net Zero
Energy Home (NZEH). In the future the net zero energy concept may be extended to a life cycle zero energy approach, as proposed by [6].

Design and construction of NZEH should have the following features:

$\checkmark \quad$ Building orientation towards climate zone;

$\checkmark$ Location of the building;

$\checkmark$ High degree of insulation of the building envelope;

$\checkmark \quad$ Optimized high-performance glazing;

$\checkmark$ Optimized use of daylighting;

$\checkmark$ Ambient lighting low density (with electronic dimmable);

$\checkmark \quad$ Control by occupancy room;

$\checkmark$ Control loads of plug and process;

$\checkmark$ Super-efficient HVAC systems;

$\checkmark$ Greater use of heat pumps;

$\checkmark \quad$ Systems Radiant heating and cooling;

$\checkmark$ The use of renewable energy.

Research and development house with zero net energy consumption is reduced to the study and optimization of a large number of specific technologies and the integration and optimization of the joint use of these technologies. Specific technologies of interest are:

$\checkmark$ production of electricity from solar energy using photovoltaic panels;

$\checkmark$ connect installation of photovoltaic panels on the electric grid (with INVENT to transform DC into AC electrical energy);

$\checkmark$ realization-layer houses with zero net energy consumption (thermal insulation, heat storage, shape, windows);

$\checkmark \quad$ ventilation-air conditioning and any living space (heat recovery);

$\checkmark$ sparingly-lighting;

$\checkmark$ saving-use kitchen appliances (Class A);

$\checkmark$ use device for power control in production and consumption. 
The effect of these technologies is seen during their lifetime, with the perceived energy used, energy is produced with the desired characteristics, and pollutant emissions. In the development of the house with a net zero consumption is viewed in the price of materials and devices on the market and produced the selling price of electricity produced by the house with zero net energy consumption and electricity in the distribution system .

The technologies that will be used in this paper for the house net zero energy, are based on the production of electricity using photovoltaic panels must produce more energy to meet the natural gas consumption for heating, so that the annual energy produced is equal to the energy purchases . Getting hot water with the use of solar panels, the next is the technology used to develop net zero home in this paper.

Integrating simulation and the common use of these technologies in the development of home with zero net energy consumption is done from the point of maximum exergy and energy efficiency, minimizing emissions of carbon dioxide and other harmful substances, and maximizing economic effects . Economic parameters of sustainability optimal solutions are payback period, the price of electricity generated, and the rate of profit during the use of the house with a net zero energy consumption.

\section{DEFINITION OF GEOMETRY OF THE OBJECT}

Before you start working in EnergyPlus is necessary to define the geometry of an object using Google SketchUp [7]. Fig. 1 shows the simulation model used in this study. To obtain the geometry required to model the object to be simulated and exported it to the EnergyPlus idf file that recognizes. Only object modeling is done in Google SketchUp to using simple tools, with the proviso that before choosing tools must be created to position the energy zone [8].

\section{The physical model of the object}

Fig. 2 shows the foundation of a house with the heating system. The Building is family residential house of 80 $\left[\mathrm{m}^{2}\right]$ designed for a family of four. The building consists of six rooms including: living room, kitchen, two bedrooms, bathroom and hallway.

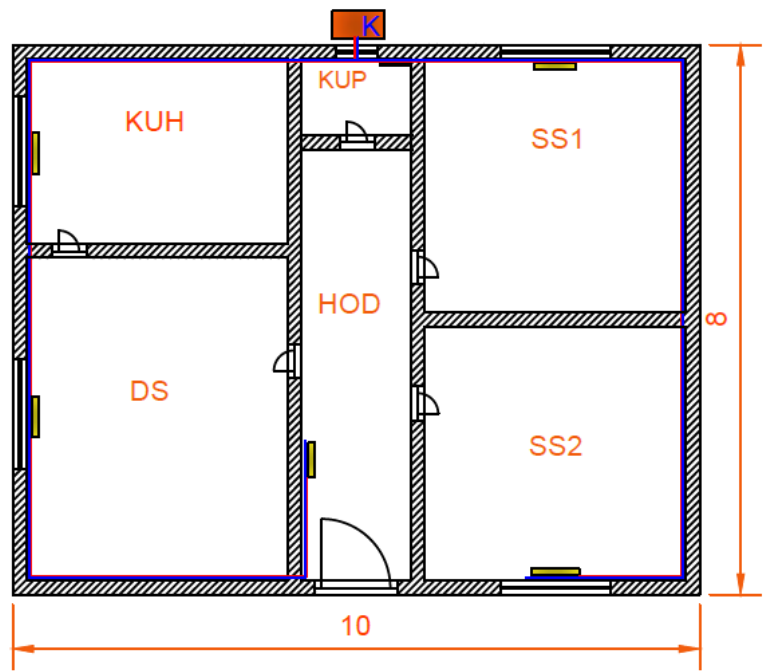

Fig. 2. The foundation of a house with the heating system

Room dimensions are given in Table 1, and the maximum height is 2.5 [m].

Rooms are marked as follows:

- DS - Living room

- $\mathrm{KUH}-$ Kitchen

- $\mathrm{KUO}$ - Bathroom

- HOD - Hallway

- $\mathrm{SS} 1$ - Bedroom 1

- $\mathrm{SS} 2$ - Bedroom 2

\subsection{Building geometry and materials}

While for the ratio "total glazed area/total floor area" is approximately $10.05 \%$, (see Table 1 ).

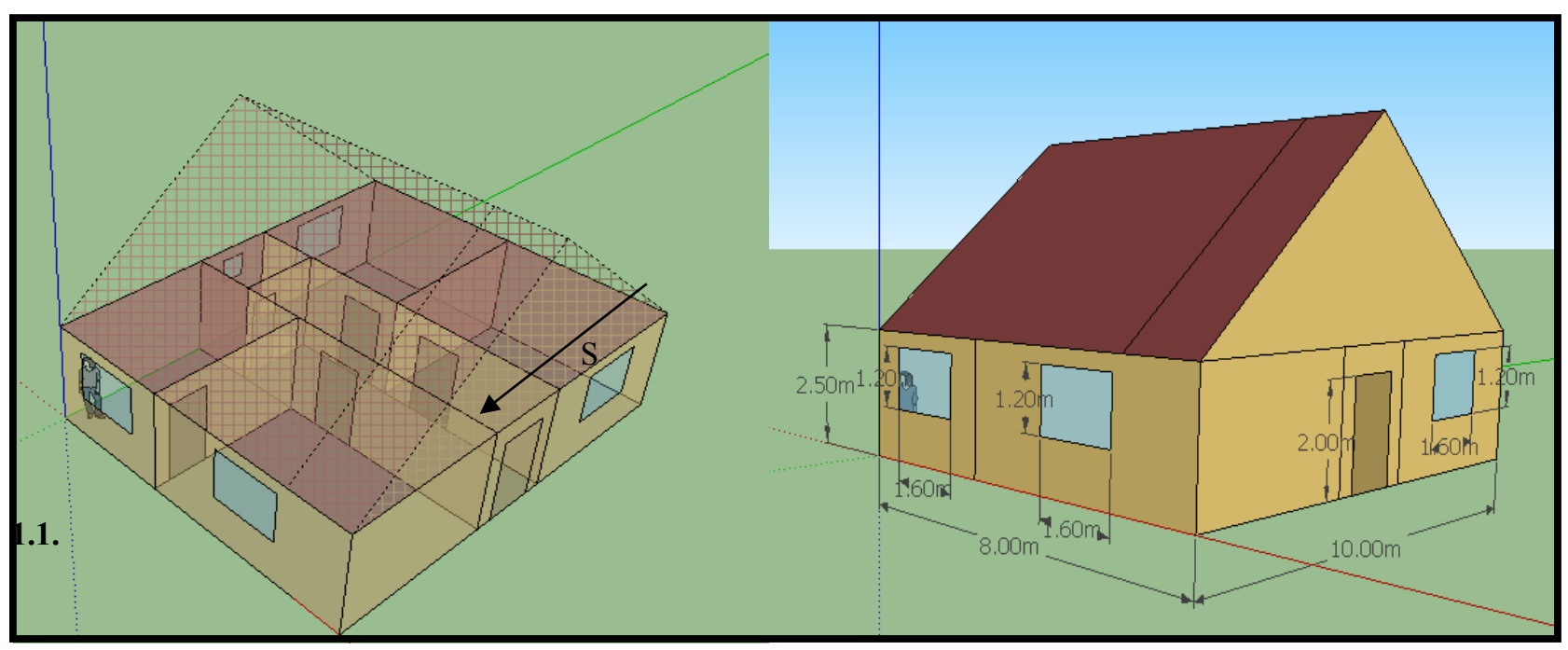

Fig. 1. The simulation model used in this study 
Table 1. Building dimensions

\begin{tabular}{cccc}
\hline Compartment & $\begin{array}{c}\text { Area } \\
{\left[\mathrm{m}^{2}\right]}\end{array}$ & $\begin{array}{c}\text { Volume } \\
{\left[\mathrm{m}^{3}\right]}\end{array}$ & $\begin{array}{c}\text { Window area } \\
{\left[\mathrm{m}^{3}\right]}\end{array}$ \\
\hline DS & 20 & 50 & 1.92 \\
KUH & 12 & 30 & 1.92 \\
KUP & 3 & 7.5 & 0.36 \\
HOD & 13 & 32.5 & 0.0 \\
SS1 & 16 & 40 & 1.92 \\
SS2 & 16 & 40 & 1.92 \\
\hline TOTAL & 80 & 200 & 8.04 \\
\hline
\end{tabular}

The internal partitions and envelope construction, listed from the outside to the inside, are the following (maximum U-values, as defined by the national thermal regulation of buildings, are presented in brackets):

- Roof: wooden cover $(0.015 \mathrm{~m})$, vapor barrier $(0.00017 \mathrm{~m})$, polystyrene insulation $(0.25 \mathrm{~m})$, vapor-permeable watertight foil $(0.00037 \mathrm{~m})$, tile $(0.015 \mathrm{~m})$. Overall U-value: $0.135 \mathrm{~W} / \mathrm{m} 2 \mathrm{~K}$. (Uvaluemax $=0.300 \mathrm{~W} / \mathrm{m} 2 \mathrm{~K}$ ).

- Floor: gravel $(0.1 \mathrm{~m})$, ferroconcrete $(0.04 \mathrm{~m})$, polyethylene foil $(0.01)$, polystyrene insulation $(0.15 \mathrm{~m})$, boards $(0.015 \mathrm{~m})$, and parquet $(0.02 \mathrm{~m})$. Overall U-value: $0.238 \mathrm{~W} / \mathrm{m} 2 \mathrm{~K}$ (no maximum defined).

- Exterior walls: Lime mortar $(0.015 \mathrm{~m})$, hollow brick $(0.25 \mathrm{~m})$, plaster $(0.015 \mathrm{~m})$, polystyrene insulation $(0.15 \mathrm{~m})$ and plaster $(0.015 \mathrm{~m})$. Overall U-value: $0.234 \mathrm{~W} / \mathrm{m} 2 \mathrm{~K}$ (Uvaluemax $=0.300$ $\mathrm{W} / \mathrm{m} 2 \mathrm{~K})$.

- Interior walls: plaster $(0.015 \mathrm{~m})$, hollow brick $(0.2 \mathrm{~m})$ and plaster $(0.015 \mathrm{~m})$.

- Windows: double glazing, Low-Emissivity. Glass Uvalue: $2.703 \mathrm{~W} / \mathrm{m} 2 \mathrm{~K}$, solar factor $\mathrm{g}=0.837$; (no maximum defined).

\section{SIMULATION SOFTWARE}

In this study, the simulation software EnergyPlus (Version 8.0) was partially used [9]. EnergyPlus is made available by the Lawrence Berkeley Laboratory in USA [10]. Its development began in 1996 on the basis of two widely used programs: DOE- 2 and BLAST. The software serves to simulate building energy behavior and use of renewable energy in buildings. The renewable energy capabilities include solar thermal and photovoltaic simulation. Other simulation features of EnergyPlus include: variable time steps, userconfigurable modular systems, and user defined input and output data structures. For Europe and different parts of the world, the software has been tested against analytical solutions, empirical results, and results of other software. The software has been tested using the IEA HVAC BESTEST series of tests [11]. The software has been verified for the building is located in Ravenna when data on real energy consumption and EnergyPlus simulations are compared. Ravenna is located in the North-East of Italy, near the Adriatic sea with latitude of $44.42^{\circ} \mathrm{N}$ that is almost equal to that of Kragujevac [12]. Next, the software gives results in good agreement to the series of experimental results of solar gain modeling in building energy codes by test cell constructed in Duebendorf, Switzerland [13]. To model, the space heating system and PV electricity generation in EnergyPlus environment, models of different components embedded in EnergyPlus are used such as that of heat pump, vertical ground heat exchanger, floor heater, and PV array $[14,15]$.

\section{CLIMATE}

The investigated residential house is located in the city of Kragujevac. Kragujevac lays in Balkan Peninsula in state of Serbia, around $120 \mathrm{~km}$ south of its capital city of Belgrade. Its average height above sea-level is $209 \mathrm{~m}$. Its latitude is $44^{\circ} 10 / \mathrm{N}$, longitude $20^{\circ} 55 / \mathrm{E}$, and time zone GMT $+1.0 \mathrm{~h}$. The EnergyPlus weather file used in the EnergyPlus simulation is generated by Meteonorm software [16].

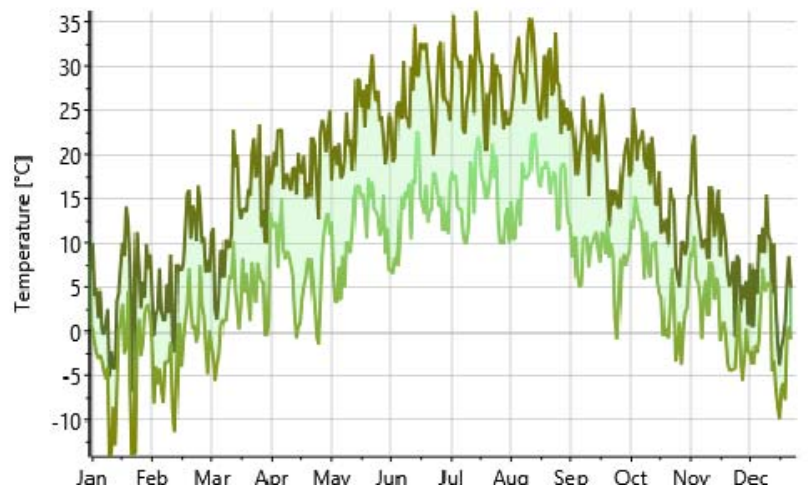

Fig. 3. Daily temperature (minimum and maximum)

To familiarize with the Kragujevac climate, Figs. 3 and 4 are given by using monthly statistics for Kragujevac from Meteonorm weather file. For each month during entire year, Fig. 3 gives the temperature (minimum and maximum). For each month during entire year, Fig. 4 shows diffuse (orange) and global (yellow) solar radiation. These figures show that the city has a moderate continental climate with a gradual transition between the four distinct seasons (winter, spring, summer, and autumn).

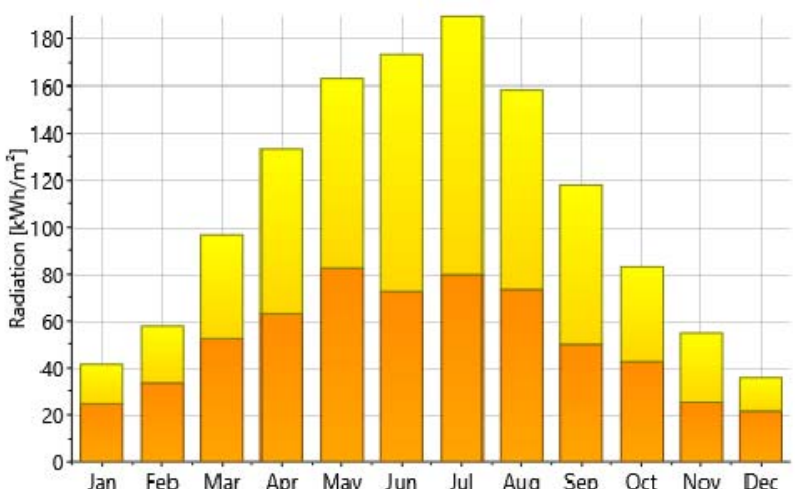

Fig. 4. Daily global radiation (minimum and maximum) 
Fig. 5. shows the Sunshine duration for each month during entire year. The red colour represent Sunshine duration [h], and yellow colour represent Astronomical sunshine duration $[\mathrm{h}]$.

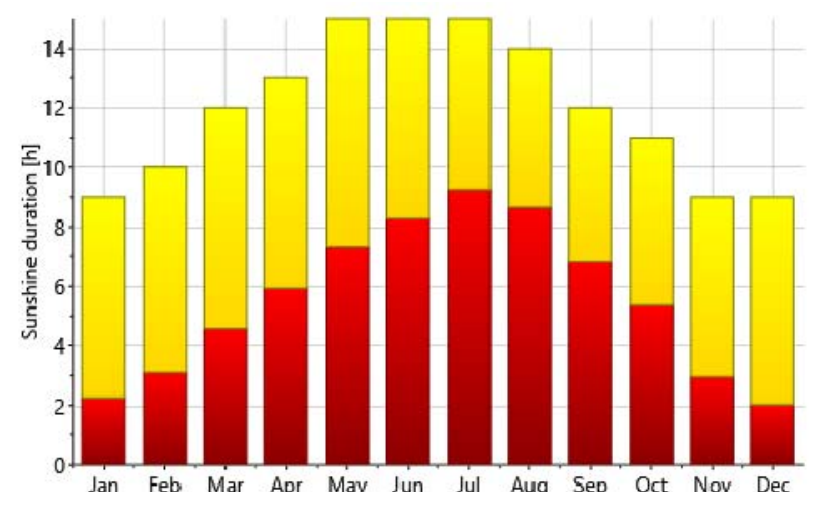

Fig. 5. Sunshine duration

\section{PV PANELS AND SOLAR COLECTORS}

\subsection{PV Panels}

The used PV panels are made from polycrystalline silicon. The PV panel is represented by the mathematical model of equivalent onediode circuit from EnergyPlus. This model consists of mathematical models for a DC current source, diode and either one or two resistors. The model simulates the operation of the PV system under real conditions using empirical mathematical equations [17]. To determine the temperature of the PV panel, the "Decoupled" method was used [17]. The model of the PV panel is developed under the assumption that it operates at its maximum power. That may not be a case when the PV system operates under the real conditions.

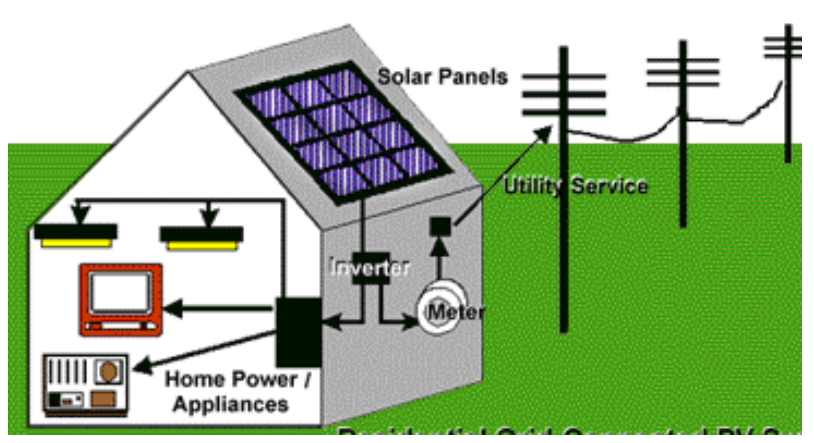

Fig. 6. PV inflicted connected to the electric grid

\subsection{Solar Collectors}

Flat plate collectors are the simplest and most common type. Copper pipes wind back and forth through the flat plate collector, which is painted black to absorb heat. The collector is covered with glass, or "glazing," to prevent heat from escaping. Often the pipes are painted black and bonded to the material of the flat plate collector Fig. 7, to maximize heat absorption [18].

A direct system, known as "open loop," Fig. 8. There is no antifreeze solution; the water heated directly by the sun is the same water used by building occupants. A thermometer and controller sense when the solar collector is warm and ready to heat water. The controller starts a pump that moves cold water into the solar collector, where it is heated.

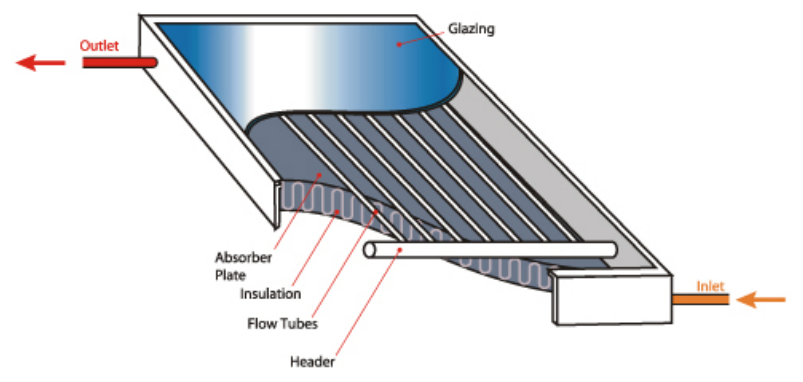

Fig. 7. Flate plate collector

The solar heated water is then stored in a conventional hot water tank. It is typical, especially during high use or periods of little sun for the water to be kept warm through supplemental gas or electricity. This type of system, because it circulates pure, potable water through an outdoor collector, is susceptible to freezing in many climates, unless safeguards are added [18].

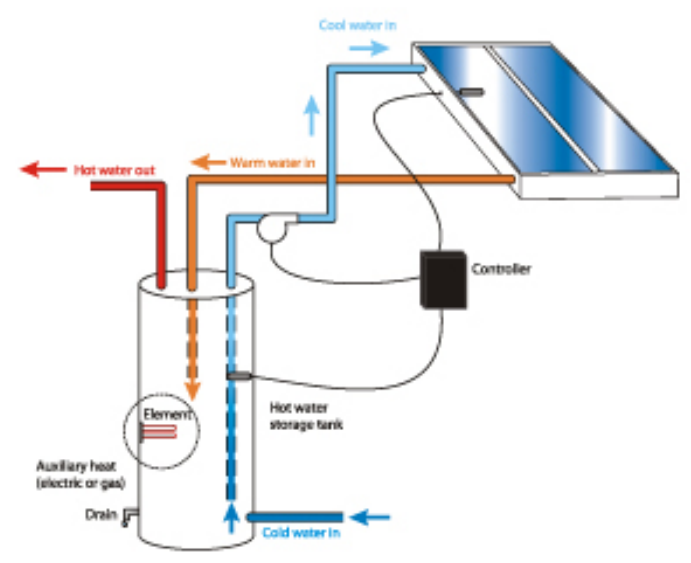

Fig. 8. Active open loop system

\section{RESULTS AND DISCUSION}

The total energy consumption of the building based on the hourly load consumption includes energy for heating buildings, heating and hot water for the operation of other devices in the household. To meet the energy demand, it was necessary to choose a particular energy source that belongs to renewable energy, that would at the same time and meet targets for zero power consumption and reduced emissions. To meet the needs of heating hot water system was chosen, which uses natural gas as fuel. The required electrical power to operate the device in the house, a supplier of solar energy is absorbed by photovoltaic panels installed on the roof of the house and turn it into electricity.

Table 2. shows the energy consumers. As electric consumers in the facility used the classics typical of every household (stove, refrigerator, TV, stereo, washing machine, freezer, microwave oven, pumps, etc.). Overall 
power consumption is $2042[\mathrm{kWh}$. Heating uses natural gas and its consumption in 1106 [kWh].

Table 2. Consumption of natural gas and electricity

\begin{tabular}{|c|c|c|}
\hline \multirow[t]{2}{*}{ Consumers } & \multicolumn{2}{|c|}{ Energent } \\
\hline & $\begin{array}{c}\text { Electricity } \\
{[k W k]}\end{array}$ & $\begin{array}{c}\text { Natural gas } \\
{[k W h]}\end{array}$ \\
\hline Heating & & 1106 \\
\hline Interior lights & 152 & \\
\hline Interior equipment & 1164 & \\
\hline Pumps & 86 & \\
\hline Water systems & 640 & \\
\hline Total and uses & 2042 & 1106 \\
\hline
\end{tabular}

Based on data simulation in Table 3. shows the results of power generation using PV panels whose area is $14 \mathrm{~m}^{2}$.

Electricity produced by PV systems in 2548 [kWh]. Since the photovoltaic system connected to the electrical grid, the excess electricity is sent to the local electricity distributor. The surplus in this case is $1852[\mathrm{kWh}]$. However, there are times when there is not enough sunshine, usually during the winter and at night, and for the house electricity taken from the grid, and 1340 [kWh]. We conclude that on an annual basis using the PV panels produced $512[\mathrm{kWh}]$ more electricity than you need.

Excess electricity produced is. $512[\mathrm{kWh}]$ settles the consumption of natural gas for heating, so that the excess energy converted into primary energy using the conversion factor which is 2.5 , so the primary energy is $1280[\mathrm{kWh}]$. Consumption of natural gas in primary energy converted using conversion factors is 1.1, so the primary energy is $1216[\mathrm{kWh}$. Based on these calculations all the energy produced by the house, she spends for its own purposes, therefore house we're talking about a net zero energy, Table 4.

Table 3. Results using PV panels

\begin{tabular}{|c|c|c|}
\hline & $\begin{array}{c}\text { Electricity } \\
{[\mathrm{kWh}]}\end{array}$ & $\begin{array}{c}\text { Percent } \\
\text { Electricity } \\
{[\%]}\end{array}$ \\
\hline Photovoltaic Power & 2547.76 & 125.15 \\
\hline $\begin{array}{c}\text { Electricity Coming From } \\
\text { Utility }\end{array}$ & 1339.98 & 65.82 \\
\hline $\begin{array}{c}\text { Surplus Electricity Going } \\
\text { to Utility }\end{array}$ & 1851.90 & 90.96 \\
\hline Net Electrical From Utility & -511.9 & -25.1 \\
\hline Total Electricity End Uses & 2035.84 & 100 \\
\hline
\end{tabular}

Table 4. Consumption of natural gas and electricity

\begin{tabular}{|llc|}
\hline Consumers & $\begin{array}{c}\text { Primary } \\
\text { energy } \\
\text { [kWh] }\end{array}$ \\
\hline Excess electricity [kWh] & 512 & 1280 \\
\cline { 1 - 2 } Conversion factor & 2.5 & \\
\hline Natural gas [kWh] & 1106 & 1216 \\
\hline Conversion factor & 1.1 & \\
\hline
\end{tabular}

In Fig. 9 shows the values of generated electricity for the month of January when the night is longer than day.

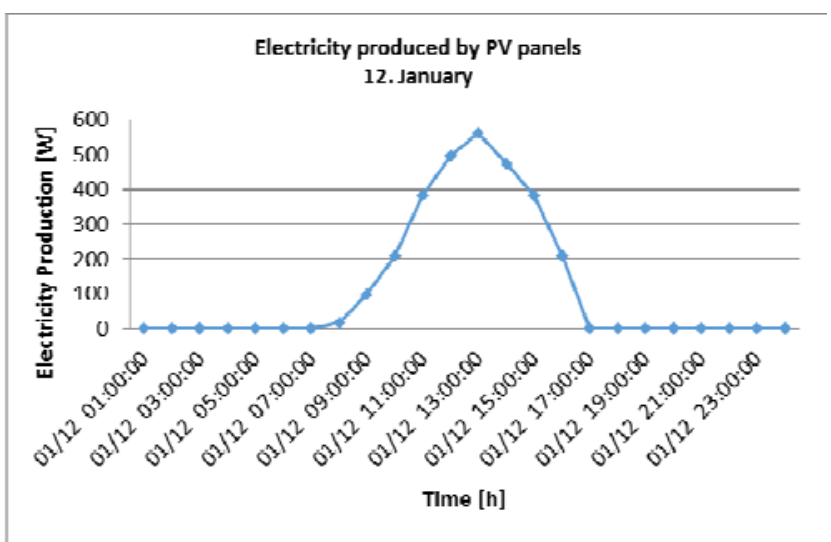

Fig. 9. Value of electricity generated by the PV panels depending on the time (winter)

FN panels produce electricity for a period of 08-16 hours [h], and over a period of 17-07 hours [h], the facility is supplied with electricity from the grid.

During the summer interval of electricity production is 05 19 [h] or increased, as the day is longer, the night when electricity is taken from the grid interval is shorter Fig. 10.

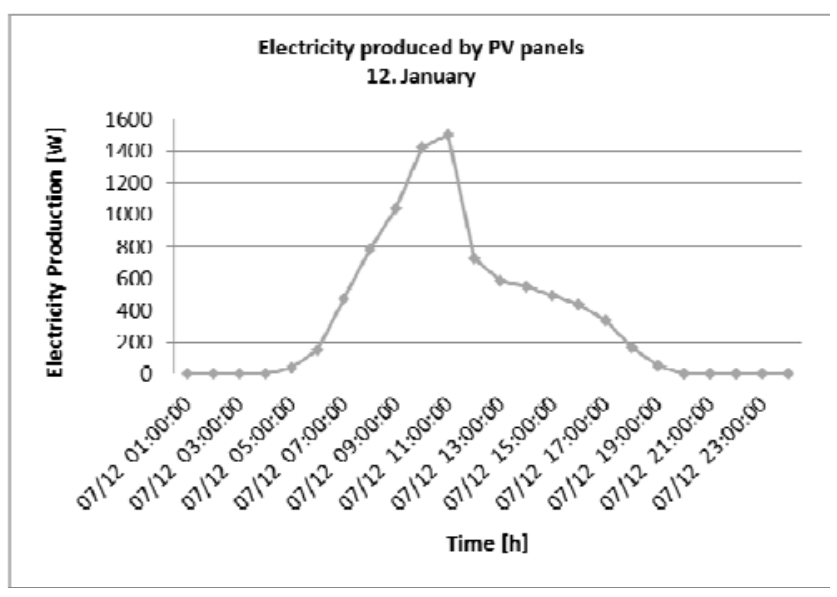

Fig. 10. Value of electricity generated by the PV panels depending on the time (summer)

Fig. 11. represents produced electricity by mounth and Fig. 12. represents electricity imported from the power grid.

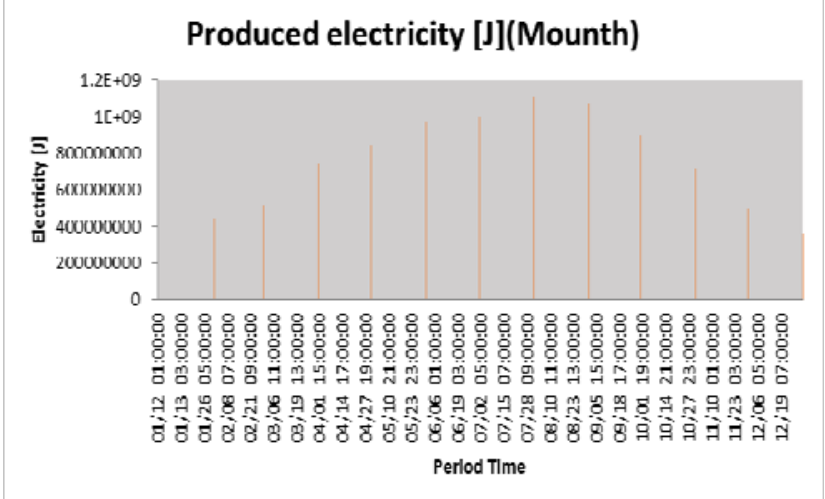

Fig. 11. Produced electricity by mounth 
Electricity imported from the power grid [J]Mounth)

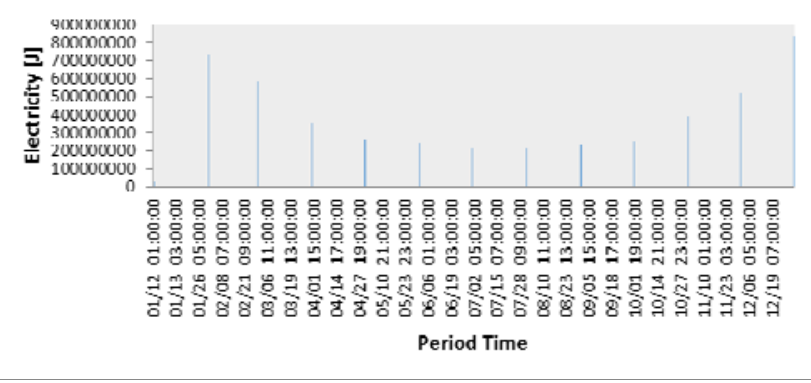

Fig. 12. Electricity imported from the power grid

In Table 3. is given a report on the production of electricity using PV panels. According to him, we conclude that annually there is a surplus of electricity generated than is needed to satisfy the consumption of natural gas for heating or energy that does not produce house. Based on Fig. 13. confirmed the results the house produces more energy than it takes in electro - networks.

$$
Q_{t v}=V \cdot \rho \cdot c \cdot\left(t_{t v}-t_{h v}\right)=m \cdot c \cdot\left(t_{t v}-t_{h v}\right)
$$

where:

$$
\begin{aligned}
& V \text { - volume } \\
& C \text { - water specific heat capacity } \\
& \rho \text { - water density } \\
& t_{t v} \text { - water maximum temperature } \\
& t_{h v} \text { - water minimum temperature }
\end{aligned}
$$

Nominal size required fields of solar:

$$
A_{P S E 1}=\frac{Q_{t v}}{q_{P S E}}=3.55\left[\mathrm{~m}^{2}\right]
$$

where:

$q_{P S E}$ - average daily insolation of Kragujevac is 3.97 $\left[\mathrm{kWh} / \mathrm{m}^{2}\right]$

The ratio of produced and purchased electricity

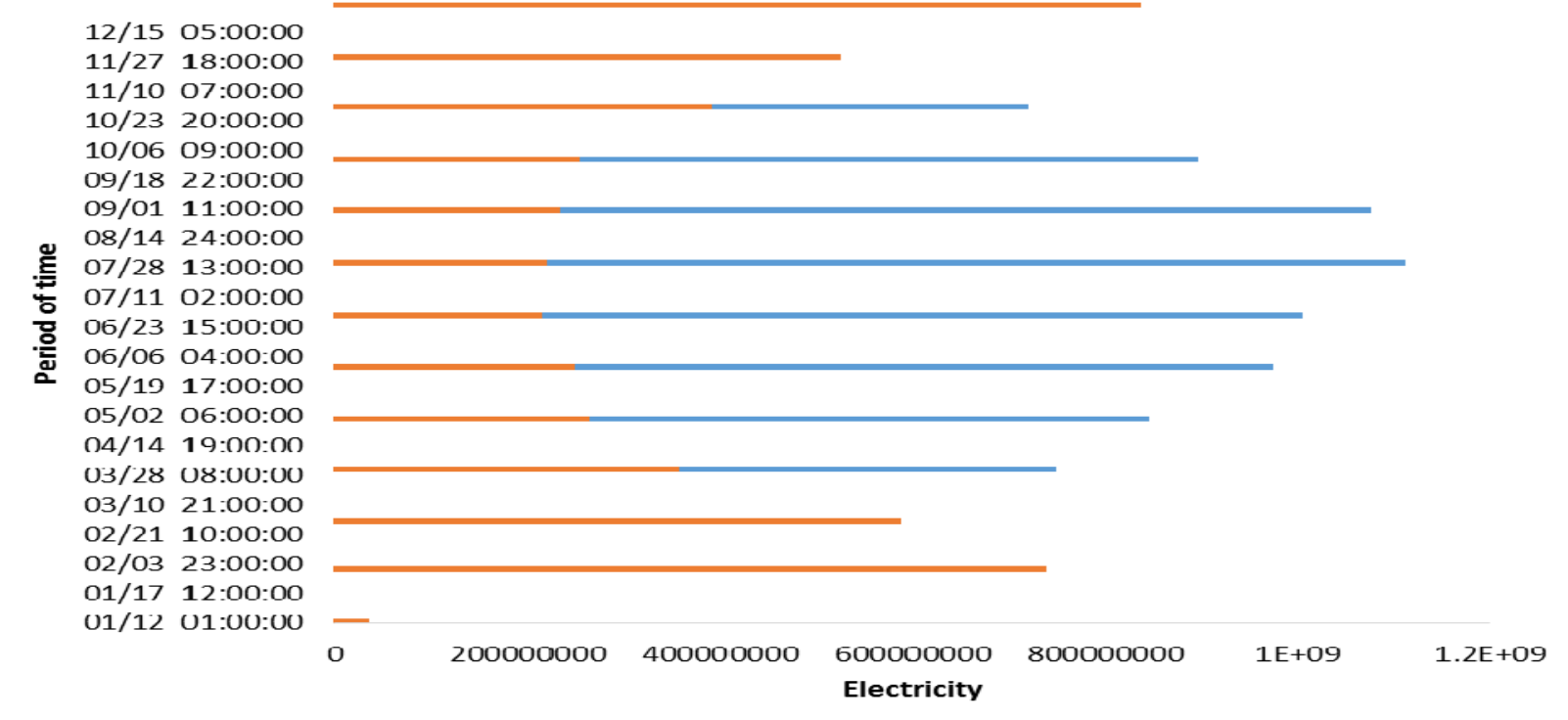

Fig. 13. The ratio of produced and purchased electricity annually

Electricity produced facility ( $\mathrm{J} /$ Monthly) is orange colour and electricity purchased facility ( $\mathrm{J} /$ Monthly) is blue colour.

Domestic hot water is used in solar colectors. Estimated daily energy consumption for showers and other domestic hot water uses based on a 751 at $43{ }^{\circ} \mathrm{C}$ for each of the 4 occupants (water will be used at maximum $40{ }^{\circ} \mathrm{C}$, but we should heat it up to $43{ }^{\circ} \mathrm{C}$ as a conservative approach that allows for distribution losses). Using a constant water supply yearly average temperature of $14{ }^{\circ} \mathrm{C}$, the annual energy demand for DHW is roughly $3212 \mathrm{Kw} / \mathrm{h}$ year (see Table 5).

Monthly energy use for domestic hot water for the fourmember household to $0.46 \mathrm{~m} 3$ per day from $14{ }^{\circ} \mathrm{C}$ to 40 ${ }^{\circ} \mathrm{C},[7]$.
Table 5. On site thermal sources (Energuplus)

\begin{tabular}{|r|r|r|}
\hline & Heat $[\mathrm{kWh}]$ & Percent Heat [\%] \\
\hline Water-Side Heat Recovery & 0.00 & 0.00 \\
\hline Air to Air Heat Recovery for Cooling & 0.00 & 0.00 \\
\hline Air to Air Heat Recovery for Heating & 0.00 & 0.00 \\
\hline High-Temperature Geothermal* & 0.00 & 0.00 \\
\hline Solar Water Thermal & 3211.49 & 100.00 \\
\hline Solar Air Thermal & 0.00 & 0.00 \\
\hline Total On-Site Thermal Sources & 3211.49 & 100.00 \\
\hline
\end{tabular}

As the total thermal efficiency of the whole system for heating domestic hot water solar energy is less than the current thermal efficiency of solar energy for thermal 
energy losses of the various components and subsystems (subsystem heat distribution, heat transfer subsystem and subsystem using hot water), the total area of field devices must be higher. Thus, the area of solar collectors for heating domestic hot water is $A_{P S E 1}=4\left[\mathrm{~m}^{2}\right]$.

Solar collectors are used to heat the hot water used for: sinks, showers, clotheswasher, dishwasher.

\subsection{Energy class}

Energy rating for the building is determined by the maximum allowable annual final energy needed for heating $\left[\mathrm{kWh} / \mathrm{m}^{2} \mathrm{a}\right]$, which is defined by the regulation on energy performance of buildings, especially for new and existing buildings.

Building energy rating is an indication of the energy performance of buildings. Was expressed by the relative value of the annual final energy consumption for heating [\%], and the percentage ratio of specific annual heat demand for heating $\left.\mathrm{Q}_{\mathrm{H}}, \mathrm{nd}\right)\left[\mathrm{kWh} / \mathrm{m}^{2}\right]$ and maximum allowable $\mathrm{Q}_{\mathrm{H}}$, nd, $\max$ ) $\left[\mathrm{kWh} / \mathrm{m}^{2} \mathrm{a}\right]$ for certain categories of buildings:

$$
Q_{H_{i} n d, r \in l}=\left(\frac{Q_{H, n d}}{Q_{H_{2} n d, \max }}\right) \cdot 100 \%
$$

Annual overall energy required for heating is 14 $\left[\mathrm{kWh} / \mathrm{m}^{2} \mathrm{a}\right]$. Building energy rating for which the calculation is performed $\mathrm{A}$. This means that $\mathrm{Q}_{\mathrm{H}}, \mathrm{nd}$,rel) $\leq$ $100 \%$ and $\left.\mathrm{Q}_{\mathrm{H}}, \mathrm{nd}\right) \leq 17\left[\mathrm{kWh} / \mathrm{m}^{2} \mathrm{a}\right]$, Table 6 Scale of the label range from $\mathrm{A}+$, which shows net zero energy performance, down to F, indicating unsatisfactory performance.

Table 6. Energy class of residential buildings [18].

\begin{tabular}{|c|c|c|c|}
\hline \multicolumn{2}{|c|}{$\begin{array}{c}\text { Building with one } \\
\text { apartment }\end{array}$} & New & Existing \\
\hline $\begin{array}{c}\text { Energy } \\
\text { class }\end{array}$ & $\begin{array}{c}Q_{H, n d, r e t} \\
{[\%]}\end{array}$ & $\begin{array}{c}Q_{H, n d} \\
{\left[\mathrm{kWh} / \mathrm{m}^{2} \mathrm{a}\right]}\end{array}$ & $\begin{array}{c}Q_{H_{n} n \mathrm{nd}} \\
{\left[\mathrm{kWh} / \mathrm{m}^{2} \mathrm{a}\right]}\end{array}$ \\
\hline $\mathrm{A}+$ & $\leq 15$ & $\leq 10$ & $\leq 12$ \\
\hline A & $\leq \mathbf{2 5}$ & $\leq 17$ & $\leq \mathbf{2 0}$ \\
\hline $\mathrm{B}$ & $\leq 50$ & $\leq 33$ & $\leq 38$ \\
\hline C & $\leq \mathbf{1 0 0}$ & $\leq \mathbf{6 5}$ & $\leq \mathbf{7 5}$ \\
\hline $\mathrm{D}$ & $\leq 150$ & $\leq 98$ & $\leq 113$ \\
\hline $\mathrm{E}$ & $\leq 200$ & $\leq 130$ & $\leq 150$ \\
\hline $\mathrm{F}$ & $\leq 250$ & $\leq 163$ & $\leq 188$ \\
\hline $\mathrm{G}$ & $>250$ & $>163$ & $>188$ \\
\hline
\end{tabular}

\section{CONLUSION}

Based on a review of different literature this paper finds and displays the set of parameters that should be considered and elaborated before the implementation of net zero energy home.

Thus, at this house, small power consumption, set up the solar system for the production of electricity that turns the building into a small power plant. All the buildings annual energy that is produced through the solar system and it consumes. How solar energy is not a reliable source because the sun does not always available, it was necessary to balance the energy produced to the network. Annual production of electricity the solar system was sufficient to cover the annual energy consumption of the house.

The disadvantage of this system that stands out most is a costly investment. Bearing in mind that this solution construction greatly reduces greenhouse gas emissions, which is now a major issue worldwide, and quality construction impact on reducing energy consumption, it can be concluded that these solutions are increasingly pursued in the future. Looking toward the future, we must ask ourselves what our main goals? Main goal is to find a solution that would require less cost, or we have to engage a little in order to influence future changes made by renewable energy sources? The sun, like a huge source of energy and a major life on Earth necessarily conveys energy, and for us to use it in the best way possible. By investing in the development of new and more effective improvements in any aspect, including with regard to energy, to create a reflection of the changes that continue into the future. If we think about energy in order to increase efficiency and efikasanost its production and utilization, we could use these buildings should certainly be near future.

\section{REFERENCES}

[1] http://www.ssllink.com/mre/cms/mestoZaUploadFajl ove/ ENERGETSKI_BILANS_PLAN_ZA_2008.pdf.

[2] http://www.biogasmax.eu/media/biogas_as_vehicle_f uel_in_the_stockholm_region_master_thesis_ellen_ martensso_096426600_1216_240920007.pdf

[3] Obradovic' D. Feed-in tariffs introduced in Serbia via regulation on promoting power generation from renewable. Energetika.net, 24th November; 2009. http://www.energetika.net/eu/iskanje? search=Dragan +Obradovic' ,+Belgrade.

[4] Voss, K., 2008. Keynote: "Net Zero Energy Buildings"; University Wuppertal; Building Physics and Technical Building Service; Zero Energy Buildings - IEA SHCP task definition Workshop, Washington, DC, USA.

[5] Marszal, A.J., Heiselberg, P., Bourrelle, P., Musall, E., Voss, K., Sartori, I., Napolitano, A., 2011. Zero energy building - a review of definitions and calculation methodologies. Energy and Buildings 43 (4), 971-979.

[6] Hernandez, P., Kenny, P., 2010. From net energy to zero energy buildings: defining life cycle zero energy buildings (LC-ZEB). Energy and Buildings 42 (6), 815-821.

[7] Sketchup2013,http://www.sketchup.com/about/sketch up-story.

[8] Anonymous, ENERGYPLUS, Input Output Reference - The Encyclopedic Reference to EnergyPlus Input and Output, University of Illinois \& Ernest Orlando Lawrence Berkeley National Laboratory, 2009.

[9] Bojic' M, Nikolic' N. Use of solar energy for operation of compressor heat pump.Report of center for heating, air conditioning, and solar energy. Faculty of Mechanical Engineering at Kragujevac, University of Kragujevac; 2009 ((in Serbian)). 
[10] Crawley D, Lawrie L, Winkelmann F, Buhl W, Huang JY, Pedersen C, et al. EnergyPlus: creating a new-generation building energy simulation program. Energy Build 2001;33:443.

[11] Henninger R, Witte M, Crawley D. Analytical and comparative testing of EnergyPlus using IEA HVAC BESTEST E100-E200 test suite. Energy Build 2004;36:855-63.

[12] Tronchin L, Fabbri K. A round Robin test for buildings energy performance in Italy. Energy Build 2010;42:1862-1877.

[13] Manz H, Loutzenhiser P, Frank T, Strachan PA, Bundi R, Maxwell G. Series of experiment for empirical validation of solar gain modeling in building energy codes - experimental setup, test cell, characterization, specifications and uncertainty analyses. Build Environ 2006;41:1784-97.
[14] Lawrence Berkeley National Laboratory. EnergyPlus engineering document: the reference to EnergyPlus calculations. Bekeley: LBL; 2001.

[15] Lawrence Berkeley National Laboratory. EnergyPlus input output reference: the encyclopaedic reference to EnergyPlus input and output. Berkely: LBL; 2001.

[16] Meteonorm. Global meteorological database for engineers. Planners and education.

[17] Trotter C. Positive energy building in Masdar, Abu Dhabi,http://inhabitat.com/2008/03/06/wold'sfirstpositive-energy-building-plannedfor masdar

[18] http://www.southface.org/learningcenter/library/solar-resources/how-solar-thermalworks

[19] Pravilnika o energetskoj efikasnosti zgrada „Službeni glasnik RS“ br. 61/2011 